The Northern Review

yukoncollege.yk.ca/review

\title{
The DEW Line and Canada's Arctic Waste: Legacy and Futurity
}

\section{Myra J. Hird}

\begin{abstract}
During the Cold War, the United States and Canada embarked on an ambitious military construction project in the Arctic to protect North America from a northern Soviet attack. Comprised of sixty-three stations stretching across Alaska, Canada's Arctic, Greenland, and Iceland, the Distant Early Warning (DEW) Line constitutes both the largest military exercise and waste remediation project in Canadian Arctic history. Despite the massive cleanup operation undertaken, the DEW Line's waste legacy endures as a prominent and deeply rooted feature of Canada's Arctic history. Drawing upon a rich historical, anthropological, military, political science, and environmental studies literature, this article explores waste as a key issue in the shifting narratives concerned with the modernization of the Canadian Arctic. While the DEW Line has been extensively analyzed in terms of its effects on the modernization of the Arctic, this article seeks to link Canadian sovereignty, security, resource exploitation, environmental stewardship, and Inuit self-determination directly to waste issues. As industrial activity and military exercises stand to significantly increase in the Arctic, I want to draw attention to the lessons of the DEW Line; that "develop now; remediate later" incurs steep human health, environmental, financial, and political costs.
\end{abstract}

\section{Introduction}

The area 60 degrees latitude north covers some 3.4 million $\mathrm{km}^{2}$, or $40 \%$ of Canada's land mass. Less than 1\% of Canada's population lives in the Arctic-most of whom are Inuit. Canada's Arctic ${ }^{1}$ is a site of shifting representations of largely neglected wasteland; commitments to sovereignty and international security needs; and contemporary tangled discourses of resource exploitation and Canadian energy interests, Inuit self-determination, and Anthropocene markers of a vulnerable planet in 
need of human stewardship. These threaded discourses are hewn from the fabric of a short but intense history of colonization, nation building, and Indigenous self-governance. ${ }^{2}$

The Distant Early Warning (DEW) Line was constructed to protect North America from a Soviet invasion via the Arctic. Sixty-three stations stretching across Alaska, Canada's Arctic, Greenland, and Iceland left behind a legacy of differential exposure of Arctic communities to waste contamination, pollution, and abandoned infrastructure. In the wake of extensive remediation, the DEW Line's waste endures as a pivotal artefact of complex and interwoven sovereignty, security, resource exploitation, and Inuit self-determination discourses. This article explores the predicates-both ideological and material-to the DEW Line's establishment, short operation, closure, and remediation. I will argue that this remainder endures within a much larger waste landscape, one that stands to significantly expand and "complexify" as the focus on resource exploitation intensifies. I will further suggest that thinking through Canadian Arctic sovereignty, security, and environmental stewardship in terms of waste is a useful contribution to these vital issues not least because waste remains a comparatively obscure corollary to nation building and Indigenous self-determination. As industrial activity and military exercises increase in the Arctic, I want to draw attention to the "waste lessons" of the DEW Line; that "develop now; remediate later" incurs steep human health, environmental, financial, and political costs.

\section{Waste and Land}

Contemporary drives toward Arctic resource exploitation are historically and ideologically shaped, in significant part, by a European JudeoChristian understanding of land and the imperative of its utilization (Saul 2008). In Old and Middle English, "waste" referred generally to the environment, and more specifically to uninhabitable land. In the 1200s, the Anglo-French word for waste meant "desolate regions" and in Old North French it referred to "damage, destruction, wasteland, or moor." By c. 1300, the Old English word "waste" meant "a desert, a wilderness" from the Latin "empty, desolate, waste." Into the 1600s, waste still referred to land that was "unfit for use." Land which appeared so desolate, and inhospitable, was synonymous with wilderness. Wilderness, in short, was wasted land: a wasteland. ${ }^{3}$

Within Judeo-Christian morality, wastelands are not only places of desolation and hostility, but also carry a certain obligation-these are 
places that may be redeemed through effort, hard work, and conviction. In his Second Treatise of Government, John Locke wrote:

God, when he gave the world in common to all mankind [sic], commanded man also to labour, and the penury of his condition required it of him. God and his reason commanded him to subdue the earth, i.e. improve it for the benefit of life, and therein lay out something upon it that was his own, his labour. (1869/2011: section 25, chapter 5)

The way to redeem idle land is to transform it - through "man's" labourinto usable, useful, and cultivated land. There needs, in other words, to be a mark on the land. Land not marked by man is land un-remarkable, unused, and unusable; again, a waste. Waste, as Scanlan moreover reminds us, is about indeterminateness: "the references to places or things that belong to neither one person nor another, its [waste] being the original condition of nature's chaos" (2005, 25, my emphasis; see also Hird 2012). Wasted and unused land is ipso facto without sovereignty.

Scanlan goes on to point out that, from this European Judeo-Christian perspective, a wasteland is effectively witness to human failure to work the land, to make it usable, and to tame nature and bring it under man's dominion. In this sense, Scanlan argues, waste and its opposite-utility and value-is "a way of knowing the material world" (Scanlan 2005, 132). Waste lands are, by definition, places beyond European Judeo-Christian comprehension.

\section{Waste and Sovereignty}

In the European tradition, waste and sovereignty are intimately connected. Sovereignty is based on land ownership and land-use rights. ${ }^{4}$ As Rob Huebert explains, sovereignty consists of "a defined territory; an existing governance system; and a people within the defined territory" $(2011,14)$. As historians have noted, in the late 1800s and early 1900s, the Canadian government's approach to the Arctic was largely one of "absentmindedness" (Shackleton 2012, 12). But by 1925, as Janice Cavell and Jeff Noakes argue, "Canada's haphazard Arctic policy had been transformed into something much more clearly thought out. Canadian officials knew exactly what they wished to claim and how, and they had defined the boundaries within which they intended to work" $(2010,9)$. At the time, this shift was more the result of European northern exploration and the Canadian government's desire to officially establish the Arctic within 
Canadian sovereignty, than it was the government's consideration of the land as especially usable or resource laden. Indeed, descriptions of the Arctic at this time most often called attention to its absolute barren state. For instance, a British Colonial Office statement from 1879 reads: "The object of annexing these unexplored territories to Canada, I apprehend, is to prevent the United States from claiming them, and not from the likelihood of their providing any value to Canada" (in Marcus 1992). ${ }^{5}$

Thus, in the early days of European exploration of the Arctic, explorers, traders, government officials, and, eventually, media correspondents described the Arctic as an uncharted, unknown, and inhospitable wasteland. For instance, a Life magazine correspondent wrote in 1963 that the Arctic "might as well be space," and that "flesh freezes solid in 30 seconds" $(1963,27)$. Even as sovereignty concerns heightened, and the Canadian government began to think of the Arctic in terms of sovereignty and resources, the territory was largely idealized as a frontier (Lackenbauer and Farish 2007) to be confronted and overcome. The Arctic involvement of the Royal Canadian Mounted Police (RCMP) and, later, the military, through the occupation of outposts and eventual construction of the DEW Line, is commonly described in glowing terms of human ingenuity and strength in taming the barren wilderness. Or, as P. Whitney Lackenbauer and Matthew Farish put it, "the construction of radar lines and associated settlements undermined the perception of Canadian wilderness as inhospitable" $(2007,923)$.

For the Inuit who had already been living in the Arctic for millennia, the territory was rich in sustenance. A growing literature documents the intimate and highly knowledgeable relationship Inuit peoples have with place: "Throughout the Arctic, all Inuit experienced a very long period in which the sea and the land provided almost everything people needed" (Qikiqtani Truth Commission 2013, 184). Inuit peoples developed complex and intimate familiarity with their regional hunting grounds:

Every geographic feature ... has names and the name is a metaphor for the totality of the group remembrance of all forms of land relatedness, of the successes and failures in hunting, it recalls births, deaths, childhoods, marriage, death, adventure. It recalls the narratives and the ancient sanctified myths ... As Inuit travel across the land, sea, and ice, they strengthen and deepen their relationships with each other and deepen their understanding of their own pasts and kin. (Williamson in Qikiqtani Truth Commission 2013, 148) 
Notwithstanding prospector and settlers' dependence on Inuit for survival, navigation, hunting, and labour (Brody 2000; Qikiqtani Inuit Association 2010; Paine 1977; Wachowich 1999), many historical accounts describe Inuit peoples as surviving in the Arctic before colonization; they did not thrive, nor live with the environment but, somehow, against all odds, managed to barely sustain themselves in such an inhospitable wasteland. Inuit peoples were not characterized as working the land in a useful Judeo-Christian fashion-planting, growing, and harvesting crops. Indeed, Inuit peoples were sometimes regarded as children in need of instruction and governance. Note, for instance, Fridtjof Nansen's preface to Diamond Jenness's The People of the Twilight, written in 1959: "One cannot read this charming narrative without getting a deep sympathy for these simple, unsophisticated children of the twilight ... a charming people of happy children, not yet stung by the burden of our culture, not burdened by the intricate problems and the acid dissatisfaction of our society" (in Jenness 1959, v). Whilst Inuit peoples had already been "stung" by colonization by this time, it is clear that from this perspective, hunter-gatherer ways of living with the land seemed not only primitive, but also idle: making no mark, utility, or command of the land rendered it a wasteland and its people in need of stewardship and proper governance (Brody 2000).

And it is within this ideological and material context that the comparatively short, yet profound, Canadian government Arctic colonization took place. In what the Qikiqtani Truth Commission calls the "official mind of Canadian colonialism" $(2013,67)$, Inuit were initially the subject of intermittent interest, as primitive but benign people barely surviving in an unimaginably harsh wasteland. In the 1950s, this view transformed as Canadian politicians became more interested in increasing Canada's sovereignty through Arctic claims, and later as a potential source of resource development and profit. In 1953, then Prime Minister Louis Stephen St. Laurent declared that a new Department of Northern Affairs and Natural Resources would officially administer the North and its peoples (who were already assumed to have been under Canadian authority). ${ }^{6}$ Where once Inuit peoples had largely thrived within their own territory, they were now increasingly seen as physical bearers of Canadian sovereignty. As such, Inuit were increasingly governed through trade with the Hudson's Bay Company, the RCMP, and other Canadian officials.

The RCMP were pivotal mediators in implementing the increasing number of regulations and policies issued from a rapidly expanding 
southern bureaucracy concerned with Arctic affairs. As Ryan Shackleton observes, "The evolution of the RCMP in the Eastern Arctic is inextricably linked to the evolution of the North. First seen by Inuit as a mixture of benefactor and punisher, the RCMP were Canada's closest tie to the Inuit of the Eastern Arctic" $(2012,19)$. The RCMP's main directive was to monitor Inuit peoples, collecting census information and vital statistics on the population. This was a complicated relationship: on the one hand, the RCMP were "responsible at times for relieving starvation, soothing illness, and saving lives (ibid, 9); whilst at the same time the RCMP were also charged by the Canadian government with enforcing the law, investigating and adjudicating complaints, collecting duties and liquor permits from traders, and monitoring and controlling animals including qimmiit (sled dogs) (see Zahara and Hird 2015). As Shackleton notes, it was "not uncommon for the police to use coercion and intimidation when dealing with Inuit," and Inuit people remember feeling both admiration and apprehension towards the RCMP (Qikiqtani Truth Commission 2013). Some of the RCMP's attitude towards Inuit people as childlike and primitive led to an inconsistent focus on self-reliance and (what the RCMP defined as) welfare handouts, and forcibly moving some Inuit families from their land in the service of Canadian sovereignty. The movement of Inuit to Arctic settlements has been variously analyzed as the intentional and devastating, sometimes brutal, displacement of Inuit (Tester and Kulchyski 1994), and as the voluntary migration of Inuit in search of more hospitable environs (including hunting and southern attractions such as housing, welfare, and labour) (Damas 2002; see also Alunik, Kolausok, and Morrison 2003). ${ }^{7}$ Inuit peoples also endured residential schooling (Truth and Reconciliation Commission of Canada 2015), various welfare and work programs (Brody 2000), housing and health-care concerns (Wenzel 1981), and military operations (Qikiqtani Truth Commission 2013).

\section{Waste and Security}

In differentiating sovereignty from security, Rob Huebert writes: "the core issue of Canadian Arctic sovereignty is control; the core issue of Canadian Arctic security is about responding to threats" (2011, 21). In the contemporary Arctic context, security has come to focus on a range of issues that have become as much about responding to environmental threats as with maintaining Canada's Arctic borders (Griffiths 2011; Lackenbauer 2011). Canadian Arctic security is closely linked with military involvement, whether in terms of DEW Line construction and operation, the various military operations launched in the Arctic such as 
operations Nanook and Nunalivut, or the potentially emerging Arctic security regime that involves enhancing "Canada's military presence and capabilities in the Arctic" through various measures including the increased presence of Canadian military personnel and its infrastructure (Lackenbauer 201, 229).

But in the wake of the Second World War, security primarily focused on the military protection of the Arctic. As tensions between the United States and the former Soviet Union grew, US Republicans, tipped off by scientists at MIT that the US was vulnerable to northern Soviet attack, began to envision a technologically advanced military response. The demand that eventuated was both simple and direct: "the Soviet Union was the enemy, war a possibility, bombers ... the threat, the polar corridor the route" (Eayers 1972, 335). Any objections concerning the high costs and ineffectiveness of the plan ended when news surfaced that the USSR had successfully tested a hydrogen bomb in 1953. In about five yearsbetween 1952 and 1957-scientists, the military, and corporate America worked in tandem to build the DEW Line. United States Secretary of Defence, Robert A. Lovett-whom William Domhoff dubbed the "Cold War architect" - contracted the response to private corporations Western Electric Corporation and Bell Technologies who worked with the US and Canadian militaries to build a number of radar stations - the Distant Early Warning Line - to stretch the width of the Arctic, from Greenland, through Canada, and on to Alaska (Pigott 2011). ${ }^{8}$

When it was completed, the DEW Line provided a two-hour warning of Soviet missiles directed at the US. As National Geographic correspondent Howard La Fay enthusiastically wrote in 1958:

In the event of an enemy attack across the polar ice, the DEW Line will flash instant warning to the joint Canadian-U.S. combat operations center at Colorado Springs, Colorado. The time thus gained could spell the difference between national life and death for Canada and the United States ... the civilian population would take cover. $(1958,129)$

While the rationale for building the DEW Line emphasized the importance of advance warning to protect American and Canadian civilian populations, Heather Myers and Don Munton (2000) argue that the real intent was to alert the Strategic Air Command (SAC) of the United States Air Force (USAF) so that it could launch a counterattack. This technological innovation proved short-lived, however, when the Soviets 
launched Sputnik in 1957, demonstrating that new ballistic missiles would allow far shorter advance warning. DEW Line sites began to close in 1963, just six years after their completion; the last one closed in 1993 (Loock 2014). Twenty-one of the sites were abandoned, becoming the responsibility of the then Canadian Department of Indian and Northern Affairs (DIAND) to remediate (Bennet et al. 2015). Twenty-one further sites were redeveloped into the new North Warning System, requiring the movement of more equipment, more infrastructure, and more military to the Arctic (Loock 2014). Nevertheless, the Dew Line's waste legacy continues: the asbestos, PCBs, and other contaminants in the soil, water, and atmosphere that have not been shipped back down south remain in the Arctic.

The DEW Line and the Pinetree Line (constructed to the south of the DEW Line, roughly along the fiftieth parallel, across southern Canada and the northern United States) are both situated within a wider military and industrial Arctic waste landscape. For instance, the North 40 site, as the Pinetree site in Iqaluit is commonly known, is just one of several waste sites located near or within the city (Hird and Zahara, forthcoming). In January 2013, a 1995 map of the city's contaminated waste sites resurfaced in the local Nunavut newspaper. A metals military dump, more than a halfcentury old, is located in the nearby territorial park, right next to the city's most popular campsite; three other waste sites, including the city's dump, are located at the causeway, the city's main launch point for those going out on the land to hunt and/or camp; and two others (a metal dump and the contaminated North 40 site) are centrally located between an airport under construction, a college residence, and the territorial penitentiary. In the newspaper article, federal and territorial politicians were asked for help in cleaning up the community's six remaining waste sites; although most (if not all) of these sites are left over from federal government military and resource development initiatives, the responsibility for cleaning up these sites remains undetermined.

And these military and industrial dump sites in Nunavut's only city exist within an even larger Arctic waste landscape. The Canol pipeline project, for instance, moved some 40,000 military personnel and civilian workers to the North in 1942 in order to secure a pipeline from Norman Wells to Whitehorse. Operational for just one year, the pipeline closed because more oil was spilled on the land than transported (Peric 2015). This military-industrial enterprise abandoned hundreds of trucks, graders, and construction equipment, as well as some 60,476 barrels of oil in the pipe, and some 108,857 barrels that are presumed to have spilled into the 
landscape (Up Here 2014, 15). Constructed in 1942 in the wake of the attack on Pearl Harbour, the Alaska Highway would eventually connect the contiguous United States to Alaska through Canada's British Columbia and Yukon. Although celebrated for taking less than a year to build, the highway was mired with technological problems caused by permafrostchallenges that still cause re-routing. The project moved thousands of tonnes of construction equipment north, and the work crews dubbed the road the "oil can highway" because of the sheer number of oil cans and fuel drums they discarded along the road. The Arctic's waste, moreover, has also accumulated "exorbitantly" (see Clark 2005): in January 1978, the Soviet satellite Cosmos 954 exploded through the atmosphere over the Northwest Territories, spreading some sixty-five kilograms of fissionable uranium-235 over an area of 124,000 km² (Heaps 1978).

In their formative article on the effects the Cold War had on militarizing the Canadian Arctic, P. Whitney Lackenbauer and Matthew Farish (2007) make the important point that the military, through Cold War operations such as the DEW Line, opened up the Canadian Arctic to emerging state sovereignty and security objectives: military involvement was key to the modernization of the Arctic itself. The authors detail how the military was instrumental in shifting perceptions of the Arctic, noting "the militarization of northern nature has been flexible enough to accommodate varying discourses of defense, protection, and security" (Lackenbauer and Farish 2007, 942). In constructing the DEW Line, for instance, the military effectively "undermined the perception of Canadian wilderness as inhospitable" (ibid, 923). And although the perception of the Arctic as a "frontier land" has not entirely diminished, Lackenbauer and Farish argue that the heavy military funding of, and involvement in, postwar scientific expeditions eventuated in the development of a "delicate Arctic" (ibid, 933) narrative from the Pierre Trudeau years onwards, leading to initiatives such as the 1990 Green Plan and the Arctic Environmental Strategy (1991-1996). It is the complex juxtaposition of oppositional and protective discourses (which include, for the authors, the fact that military operations have increasingly taken place alongside scientific studies in the Arctic) that lead Lackenbauer and Farish to stop short of characterizing the military's rendering of the Arctic as a "sacrifice zone," as the Nevada and New Mexico nuclear test sites have been characterized (Krupar 2013; Masco 2006). Whether or not military activity in the Arctic has devastated the peoples and landscape to a degree and kind sufficient to warrant this classification, Lackenbauer and Farish are unequivocal in acknowledging the devastating effects of the military: "Cold War military activities in 
the Canadian North ultimately constitute part of a global 'treadmill of destruction' tying militarism to environmental and political injustice" $(2007,942)$. It is to the military's DEW Line waste legacy that I now turn.

\section{Waste and the DEW Line}

The DEW Line construction cost approximately $\$ 7$ billion dollars, and involved 23,000 workers and 45,000 planeloads of radar equipment and machinery: 42,000 tonnes of steel, 284 million litres of fuel, 20,000 tonnes of food, and 5 hectacres of bed sheets (Capozza 2002, 14; Ducharme 2004). In a rather understated fashion, Kevin O'Reilly remarks there's "no question that the DEW Line dramatically changed the Arctic-economically, socially-but also environmentally" (in Capozza 2002, 16).

Of the total 63 DEW Line sites, 42 are in Canada, and 21 of these Canadian sites have now (as of 2014) been remediated through a series of four agreements in 1996, 1998, 2001, and 2005 involving Aboriginal Affairs and Northern Development Canada (AANDC), the Department of National Defence (DND), and Nunuvut Tunngavik Incorporated (Loock 2014). The DND announced that it had completed its remediation program in 2014 (DND 2014).

When the DEW Line was officially abandoned, most of the American and southern Canadian workers (who made up almost all of those employed to build and maintain the line) returned south (Ducharme 2004). They left in their wake 63 abandoned sites contaminated with various toxic chemicals that have had to be removed, in some cases, square centimetre by square centimetre, to southern Canada for treatment (typically burial in a landfill or incineration) at an estimated cost of over $\$ 500$ million.

The various DEW Line remediation projects have uncovered an extensive list of contaminated and uncontaminated waste: waste oil, PCB transformers/capacitors, asbestos, sewage, lead-based paints, radioactive tubes, scrap metal, radar components, fuel barrels, lime, antifreeze, wood, aviation fuel, sulfamic acid, cathode ray tubes and screens, filtron tubes, oscillators, meters, copper wire, transmission fluid, 1-1-1-trichloroethane, PBX telephone equipment, mercury vapour rectifier tubes, paint thinners, batteries, chlorinated hydrocarbons, corrosion inhibitors, lye, corrosives, paper, plastic, solvents, dynamite, RF interference filters, generators, scopes, vehicles, and rubber fuel bladders (Environmental Sciences Group and UMA Engineering Ltd. 1995). Over 30 tonnnes of polychlorinated biphenyls (PCBs) were found up to $15 \mathrm{kms}$ away from various sites. 
Scientific reports detail the scale of the remediation. At Resolution Island alone, which Scott Mitchell (DIAND director of the contaminated sites remediation) estimates cost a third of the total DEW Line remediation expense, scientists found that over 8,000 kg of pure PCBs (Aroclor 1260) had been abandoned after the site closed (Kalinovich et al. 2008). These PCBs had migrated through a valley, descended cliffs, and moved into Frobisher Bay, from which local Inuit fish. The fuel and oil that had also been openly dumped had forged a path for the PCBs, facilitating their migration over the land and into the sea. Describing the scene scientists found at Resolution Island, Canadian hazardous waste specialist Robert Eno said: "Looking at what you'd found there, you'd think that Americans took big hoses and sprayed PCB liquid all over the site" (in Capozza 2002, 15). PCBs are a known carcinogen, increasing the incidence of cancer, bacterial infections, liver lesions, and genetic defects with exposure. PCBs have shown up in polar bears, foxes, voles, trout, and other country food upon which Inuit depend (Danon-Schaffer 2015). This site alone cost $\$ 64.75$ million to remediate, and involved some 595 people in the operation (Kalinovich et al. 2008). ${ }^{9}$

Oil spills in Hooper Bay, Cape Romanzof, and Point Hope amount to some 80,000 gallons $\left(303 \mathrm{~m}^{3}\right)$ of petroleum leaked into the environment. Some of the barrels contained petroleum products (fuel, lubricants); antifreeze (glycols); degreasers (halogenated aliphatics); and cadmium, chromium, lead, and chlorine, as well as the staggering amounts of PCBs. But scientists found the highest levels of PCBs at the Sarcpa Lake site, as well as solvents, mercury, and petroleum products; buildings and other infrastructure; and abandoned barrels, sewage, and other debris (Poland, Mitchell, and Rutter 2001). At the Iqaluit and other DEW Line and Pinetree sites, scientists had to remove not only the buildings, which had asbestosclad piping, but also thousands of barrels abandoned from the DEW Line project, and those left on the site from more recent industrial activities.

Waste remediation in the Arctic often requires physically moving contaminated waste to southern disposal facilities, which are completely absent in the Arctic due to their very high associated costs, and physical challenges such as permafrost (see, for instance, Thomassin-Lacroix 2015). At the Iqaluit site, not only did the buildings require demolishing, but also the concrete foundations had to be removed and shipped south for disposal-according to the DEW Line Cleanup (DLCU) Protocol (2005)because the PCBs had entirely penetrated the concrete to 50 to $70 \mathrm{~cm}$ (the DLCU Protocol requires PCBs at more than $50 \mathrm{ppm}$ to be shipped to a licensed disposal facility). The PCB-contaminated drums found at the 
DEW Line site in Iqaluit had to be flown from Iqaluit to Yellowknife, and then land-transported to a PCB incineration facility in southern Canada (Poland, Mitchell, and Rutter 2001). Some further 307 metres $^{3}$ of soil contaminated at the DCC Tier II level (5-50 ppm) was placed in specially designed fabric boxes and shipped to a waste disposal site near Montréal. Engineers had the extra challenge of designing viable landfills that could be excavated in hard rock and permafrost. Technologies used in the South such as incineration, thermal desorption, and solvent extraction prove to be unviable in the North as they are too expensive, require very large amounts of fuel (which would need to be shipped north), produce residues that must be shipped south for disposal, or incompletely deal with the contamination. Describing the Resolution Island cleanup, scientists noted the unique challenges of waste remediation in the North: "The magnitude of the PCB contamination is very large, the terrain mountainous, the site extremely remote, the climate is particularly harsh and polar bears are regular visitors" (Poland, Mitchell, and Rutter 2001, 96).

And although the term "cleanup" suggests that scientists have been able to return the sites to their pre-construction condition, remediation has been the more attainable goal. Discussing the lengthy assessment of the feasibility of cleaning up the DEW Line sites, the ESG report concedes, "The Protocol recognizes that this restoration will not return the environment to a pristine state, but will at least remove most barriers to long-term natural reclamation" (1993, 30). And, further, as Heather Ducharme (2004) observes, whether the terms "cleanup" or "remediation" are used, both actually involve further material development of landfills and burns. Even the assessment process has involved further environmental disturbance: The "environmental sampling to survey the damage has involved some 4,000 soil/sediment/water, 1,600 plant, and 500 marine/animal tissue samples" (ibid, 15). Moreover, much of the material brought to the Arctic has-if it is below the protocol's threshold for contamination-been left there. And the vast quantities of material (soil, barrels, and so on) that are so contaminated that they must be removed to the South are then not cleaned up but rather buried in southern landfills or incinerated, a process that produces highly toxic fly ash that must then be stored in specially designed facilities (Rowe 2012). 


\section{Waste, Sovereignty, Security, Stewardship, and Self-Determination Revisited}

The dramatic increase in demand for northern natural resources over the past twenty years has only intensified with the prospect of climate change making these resources more accessible by way of, for instance, opening up the Northwest Passage to year-round shipping (Hird and Zahara forthcoming, Southcott 2012). Although the exact industrial prospects are unknown, according to then Aboriginal Affairs and Northern Development Canada, the North contains about $25 \%$ of Canada's discovered recoverable crude oil and natural gas, and about $40 \%$ of Canada's projected future discoveries (Government of Canada 2010). Foreign companies such as British Petroleum are making enormous bids for exploration rights, and countries such as China and India are seeking non-Arctic observer status at the Arctic Council (Griffiths, Huebert, and Lackenbauer 2011). Much depends on a number of factors that remain uncertain at this time: what proportion of what resources (oil, gas, gas hydrates, minerals, and so on) will be uncovered, at what costs, and with what developed technology, and in what market climate? These unavoidable uncertainties also mean uncertainties in the amounts and kinds of waste production as a result of this industrial and military push in the Arctic. In simple terms, more people and equipment moving temporarily from south to north, and much more drilling and extraction, inevitably means more waste. And although, as we saw earlier, Lackenbauer and Farish stop short of identifying the Arctic as a "sacrifice area," they are clear about the devastating impacts of the military/industrial presence in the Arctic. Referring to the Arctic, they observe:

\footnotetext{
These military mega-projects radically transformed the human and physical geography of the North. Bulldozers tore permafrost off the ground disrupting ecosystems and creating impassable quagmires. Forest fires, logging, over-hunting, and over-fishing depleted resources in the region. Arriving workers brought diseases from measles and VD, which devastated indigenous populations. (2007, 925. See also Kafarowski 2004; Sandlos and Keeling 2012)
}

Some scholars have pointed out that the DEW Line was a triumph for Canadian sovereignty, because it established the Arctic as Canadian territory and the US government largely paid for its construction (Lackenbauer 2011). Others suggest that resource development may 
provide much-needed employment for young Inuit people (Huebert 2011). However, Huebert is also cautious:

But at the same time, these opportunities may result in serious problems. It is already known that megaprojects often result in serious social problems such as drug and alcohol abuse. Increasing suicide rates are also often associated with societies in transition. Improvements in the economic security of the region may come at the cost of societal security. (ibid, 22)

Thus, amongst whatever dividends Inuit may or may not actually accrue-and numerous studies demonstrate that many are peripheral and temporary, a problem associated with what is known as the "staples trap" or "resource curse" (see Southcott 2012, for example)-northern development ultimately leaves substantial waste in its wake:

Today, the greatest and certainly the most direct threat to the security of Arctic residents stems from damage to the environment. The Arctic, in effect, has been treated as a dumping ground by government, military establishments and industries concerned only with the needs of southern societies. (Simon in Shadian 2006, 256)

Inuit leaders are faced with myriad challenges in attempting to negotiate with the Canadian government as well as with national and international corporations for employment opportunities, capacitybuilding training, much-needed infrastructure investment, community investment, tourist trade, investments in health, and environmental protection (Bravo 2006). Inuit leaders such as Nellie Cournoyea have been pivotal in securing Inuit companies' participation and leadership in natural resource development initiatives (CBC 2016).

Given that corporate interest in the Arctic is almost certainly going to increase, Arctic scholars, Inuit representatives, the media, and government alike tend to argue for both the further formation of international and national regulations regarding development, as well as their careful monitoring. Lackenbauer suggests that "overall, [the] government's commitments to invest in more military capabilities for the North are reasonable and proportionate to probably short- and mediumterm threats" $(2011,106)$. These threats include climate change, which is precipitating melting permafrost and sea ice, as well as various pollutants, including contaminants of emerging concern that migrate northwards to 
be consumed by flora and fauna and, ultimately, local people (DanonSchaffer 2015). Insofar as the Arctic is becoming a repository for the world's waste, the Arctic is the Anthropocene's waste legacy.

Inuit leaders are highly active in their attempts to protect their communities and Arctic environment. In two recent Declarations, $A$ Circumpolar Inuit Declaration of Sovereignty in the Arctic (2009) and A Circumpolar Inuit Declaration of Resource Development Principles in Inuit Nunaat (2009), Inuit peoples from Arctic countries are unambiguous about their sovereignty in the Arctic, and the principles upon which they want northern resource exploitation to take place:

Inuit desire resource development at a rate sufficient to provide durable and diversified economic growth, but constrained enough to forestall environmental degradation and an overwhelming influx of outside labour. (A Circumpolar Inuit Declaration of Resource Development Principles in Inuit Nunaat 2009)

Much of the development principles explicitly refer to waste issues, including the need for:

- reclamation and recovery of habitat and affected lands and waters that is thoroughly planned and fully funded;

- complete environmental assessment after a project has been completed or abandoned;

- zero-volume discharge onto land and into Arctic waters;

- prevention of spills offshore and eliminating the release of toxic substances;

- the establishment of an international liability and compensation regime for contaminants of lands, waters, and marine areas resulting from offshore oil exploration and exploitation; and

- the adoption of the precautionary principle and the polluter pays principle. $^{10}$

The Environmental Sciences Group Report (1995) repeatedly suggests that the DEW Line was constructed at a time when less was understood about contamination and its effects, and that it is for this reason that such widespread and damaging contamination occurred: "It became apparent that many substances, including PCBs, had been 'poured down the drain' or in areas adjacent to buildings" (ESG 1993, 16). This proposition is challenged by the more recent dumping by military and industry in the 
Arctic in the name of resource exploitation, sovereignty, and security. And it is also more generally challenged by the fact that our knowledge will always be in a state of flux as we increase our knowledge of the harmful effects of waste contamination. Thus, we must be cautious about justifying environmental degradation in the name of partial knowledge, since this is science's constant state.

As such, Inuit leaders are well justified in forefronting the precautionary principle as an organizing tenet for all present and future resource exploitation. The DEW Line, as a waste legacy, strongly suggests that a "develop now; pay later" approach incurs profound environmental and human health consequences, particularly for Inuit peoples. Much will depend upon the Canadian military's emerging role in environmental protection: to date, the military's focus has been on traditional sovereignty and security concerns that increasingly include providing material, infrastructure, and personnel support for resource exploitation. Insofar as the Arctic's waste legacy may be utilized to consider future Arctic waste scenarios, Canada's northern strategy must redefine the responsibilities of military and industry in terms of waste prevention and remediation as a critical part of Canadian sovereignty, security, and environmental protection.

\section{Acknowledgements}

The author gratefully acknowledges the financial support of the Social Sciences and Humanities Research Council of Canada (Insight Grant number 435-201300560) in conducting this research; Shenique Turner's research assistance in gathering background information; and the thoughtful reviews of an earlier version of this paper.I am most grateful to the reviewers for recommending sources that significantly changed the direction of the paper's arguments.

\section{Author}

Myra Hird is professor, FRSC, and Queen's National Scholar in the School of Environmental Studies at Queen's University in Kingston, Ontario; director of the genera Research Group (gRG); and director of Waste Flow (www.myrahird.com). 


\section{Notes}

1. This paper adopts P. Whitney Lackenbauer's designation of the Arctic as the area in Canada north of the treeline, and Inuit Nunaat, which is made up of the "land and marine areas of the Nunatsiavut, Nunavik, Nunavut, and Inuvialuit land claims settlement areas" (2011,71).

2. This article refers to "southern" and "northern" as political designations. This designation does not obviate the fact that Indigenous peoples live in southern communities, nor is it meant to obscure the fact that colonial legacies exist in southern Canadian communities.

3. As William Cronon details, the Bible is replete with references to wilderness as wasteland, "places on the margins of civilization where it is all too easy to lose oneself in moral confusion and despair" $(1996,8)$. Wilderness is where Moses wandered with his people for forty years, nearly forsaking God and resorting to idol worshipping. And it is in wilderness that Jesus Christ endured forty days and was tempted by the devil. Adam and Eve were cast out of Eden to wilderness, where they and their descendants endured pain, suffering, and hardship. Land in "its raw state," writes Cronon, "had little or nothing to offer civilized men and women" $(1996,9)$.

4. As John Ralston Saul observes, "the European tradition is that you can own land, while you merely pass through water" $(2008,301)$. As opposed to the European distinction between land (useful, owned, sovereign) and water (for passage), within Inuit traditions land, ice, and water are one. Sheila Watt-Cloutier, former Chair of the International Inuit Circumpolar Council pointed out: "As Canadians seek to assert our sovereignty in the Arctic, we must remember that history is on our side, that Inuit travelled an icy highway through the Northwest Passage long before more recent arrivals even considered a fast route west" (2007, my emphasis).

5. When Britain transferred what was then known as the Arctic Islands to Canada in 1880, Danish and American explorers had already begun to circumnavigate parts of the North, sometimes encountering Inuit peoples. Around this time Greenlanders were regularly hunting muskox on Ellsemere Island, and parallels between the Aboriginal cultures of both countries were clearly apparent. The US, it was feared, would also soon lay claim to the North. With this in mind, the Canadian government made a number of declarations of sovereignty, and dispatched RCMP personnel to Ellesmere Island, Pond Inlet, Baffin Island and other regions considered most likely to incur sovereignty claims from Greenland, Norway, the Soviet Union, or the United States. This was not altogether paranoia: in 1904 Otto Sverdrup did lay claim to a region west of Ellesmere Island in the name of the Norwegian King Oscar II; a claim only settled in 1930 when Norway officially recognized Canadian ownership. 
6. This presumption was necessary in order to make the very claim of sovereignty. In other words, Inuit peoples had to be Canadian in order for Canada to assert its sovereignty over the land in which Inuit peoples lived and had lived for many generations before the federation of Canada.

7. Lester Pearson, then secretary of state for external affairs, urged the Cabinet to employ some means to preserve Canadian sovereignty over the vast wastelands of the Arctic. As the 1933 International Court of Justice case said, human activity was essential to sovereignty, and relocating the Inuit from cramped conditions in northern Quebec to the high Arctic was a solution to the "Eskimo problem" (Pigott 2011, 226-227).

8. When Canada forged an agreement with the United States to build the DEW Line, Canadian officials attempted to mitigate their compromised position with detailed directives. The Canada-United States Establishment of a Distant Early Warning System: Agreement between Canada and the United States of America (1955) explicitly specified: Canadian sovereignty; that the infrastructure would be built by mutual agreement between both countries; that the plans would need Canadian approval; Canada would have the right to inspect all construction work; that Canadian contractors would have "equal consideration," and that Canadian labour would be preferentially considered; that any scientific data collected during the construction and maintenance of the Line would be shared between both countries; that Canada would play a decisive role in the operation of the sites; and that affected "Canadian Eskimos" would enjoy limited protections. Yet, when Canadian representatives visited the DEW Line sites, they found that most were only flying the US flag. Moreover, all Canadian personnel working on the line had to, by US policy, have a US security check, and be supervised by an American. After much political wrangling with American officials over several years, with further stalls by the US Congress, the US eventually agreed to pay \$100 million - in 1995-96 dollars - towards remediation, and this was in the form of credit towards the Canadian government buying US military equipment (essentially spare parts). In the "ex gratia" agreement, the United States expressed that "it is the view of the United States government that it has no legal obligation under current US and international law to reimburse the costs of environmental cleanup" and that the agreement was a "full and final settlement of all claims for costs of environmental cleanup at the four installations" (referring to the DEW Line, the USAF base at Goose Bay, the US base at Argentia in Newfoundland, and the failed Haines-Fairbanks pipeline). In all, the US has contributed about one-fifth of the cost of remediating one-quarter of the DEW Line sites.

9. By 1988, PCBs had shown up in the breast milk of Inuit women living in Baffin Island, the Northwest Territories, and northern Quebec. These PCB levels were five times higher than in women's breast milk in any southern parts of Canada, and are the highest concentration ever found in women except for those directly involved in industrial accidents (Myers 2001). 
10. Canada's Department of Foreign Affairs and International Trade (2010) Statement on Canada's Arctic Foreign Policy: Exercising Sovereignty and Promoting Canada's Northern Strategy Abroad devotes less space to waste concerns, but does state that "Canada will continue to address the problems arising from these contaminants (POPs), including waste management practices in the North, and will engage actively in global negotiations to reduce mercury emissions" (in Griffiths, Huebert, and Lackenbauer 2011, 269; my emphasis).

\section{References}

Alunik, I., Kolausok, E.D., and D. Morrison, eds. 2003. Across Time and Tundra: The Inuvialuit of the Western Arctic. Vancouver: Raincoast Books.

Anderson, E. and S. Bonesteel. 2008. Canada's Relationship with Inuit: A History of Policy and Program Development. Ottawa: Minister of Indian Affairs and Northern Development and Federal Interlocutor.

Bennett, J.R., Shaw, J.D., Terauds, A., Smol, J.P., Aerts, R., Bergstrom, D.M., Blais, J.M., Cheung, W.W.L., Chown, S.L., Lea, M.A., Nielsen, U.N., Pauly, D., Reimer, K.J., Riddle, M.J., Snape, I., Stark, J.S., Tulloch, V.J., and H.P. Possingham. 2015. "Polar Lessons Learned: Long-Term Management Based on Shared Threats in Arctic and Antarctic Environments." Frontiers of Ecological Environments 13(6): 316-324.

Bernauer 2012. "The Uranium controversy in Baker Lake." The Canadian Dimension. Accessed 20 May 2015. https://canadiandimension.com/articles/ view/the-uranium-controversy-in-baker-lake.

Bravo, M. 2006. "Science for the People: Northern Field Stations and Governmentality." British Journal of Canadian Studies 19(2): 221-246.

Brody, H. 2000. The Other Side of Eden: Hunter-Gatherers, Farmers, and the Shaping of the World. Vancouver: Douglas and McIntyre Publishing Group.

Canada-United States. 1955. Establishment of a Distant Early Warning System: Agreement between Canada and the United States of America, Effected by an Exchange of Notes Signed at Washington, 5 May 1955. Ottawa: Canada Treaty Series, 1928-1964.

Capozza, K.L. 2002. "Ditched Drums and All." Bulletin of the Atomic Scientists Jan/ Feb: 14-16.

CBC News. 2015. "Clyde River's Fight Against Seismic Testing in Federal Court." CBC News North. Accessed 20 May 2015. http://www.cbc.ca/news/canada/ north/clyde-river-s-fight-against-seismic-testing-in-federal-court-1.3039744.

CBC News. 2016. "End of an Era for Nellie Cournoyea, the 'Iron Lady' of the North." Accessed 2 May 2016. http://www.cbc.ca/news/canada/north/ iron-lady-of-north-nellie-cournoyea-1.3407161. 
Clark, N. 2005 “Ex-orbitant Globality." Theory, Culture and Society, 22(5): 165-185.

Contenta, S. 2012. "DEW Line: Canada is Cleaning Up Pollution Caused by Cold War Radar Stations in the Arctic." The Star.

Cronon, W. 1996. "The Trouble with Wilderness; Or, Getting Back to the Wrong Nature." Environmental History 1(1): 7-28.

Damas, D. 2002. Arctic Migrants, Arctic Villagers: The Transformation of Inuit Settlements in the Central Arctic. Montreal and Kingston: McGill-Queen's University Press.

Danon-Schaffer, M. 2015. “Dumps, Landfills and Emerging Contaminants in the Canadian North." 2015 RPIC Federal Contaminated Sites Regional Workshop, Edmonton Alberta.

Department of Indian and Northern Affairs. 2005. Abandoned Military Site Remediation Protocol. Ottawa: DIAND.

Department of National Defence (DND). 2014. The Distant Early Warning (DEW) Line Remediation Project. Ottawa: DND.

Accessed 1 April 2016. http://www.forces.gc.ca/en/news/article. page?doc=the-distant-early-dew-line-remediation-project/hgq87xvs.

Ducharme, H. 2004. "Here We Fight the Coldest War: Environmental Science and Feminist Autobiography of the DEW Line." MES thesis, York University.

Eayers, J. 1972. In Defence of Canada: Peacemaking and Deterrence. Toronto: University of Toronto Press.

ESG. Environmental Sciences Group and UMA Engineering Ltd. 1995. DEW Line Cleanup: Scientific and Engineering Summary Report. Canada: Minister of National Defence.

Farish, M. 2006. "Frontier Engineering: From the Globe to the Body in the Cold War Arctic. The Canadian Geographer 50(2): 180-194.

Government of Canada. 2010. High Investment Potential in Canadian Northern Oil and Gas. Accessed 9 August 2014. https://www.aadnc-aandc.gc.ca/eng/110010 0037174/1100100037175.

Government of Canada. 2014. Canada's Northern Strategy. Accessed 9 August 2014. http://www.northernstrategy.gc.ca/index-eng.asp.

Griffiths, F. 2011. "Towards a Canadian Arctic Strategy.” In Canada and the Changing Arctic: Sovereignty, Security, and Stewardship, edited by F. Griffiths, R. Huebert, and P.W. Lackenbauer, 181-226. Waterloo: Wilfrid Laurier University Press.

Harris, L.T. The Dew Line Chronicles: A History. Accessed 4 January 2015. http:// lswilson.dewlineadventures.com/dewhist-a.htm.

Heidt, D. and P.W. Lackenbauer. 2012. "Sovreignty for Hire: Civilian Airlift Contractors and the Distant Early Warning (DEW) Line, 1954-1961." Canadian Aerospace Power Studies: 95-112. 
Hird, M.J., and A. Zahara. “The Arctic Wastes.” In Anthropocene Feminism, edited by R. Grusin. University of Minnesota Press (forthcoming).

Hough Woodland Naylor Dance Leinster, Duke Engineering Services (Canada) Inc., Angus Environmental Ltd., Michael Michalski Associates, and DS-Lea Associates. 1998. The Arsenal Lands: Park and Site Remediation Master Plan.

Hudson's Bay Company. Inuit Recollections on the Military Presence in Iqaluit. 19381939; 1939-1940. Hudson's Bay Company, Pagnirtung Post Journal.

Huebert, R. 2011. "Canadian Arctic Sovereignty and Security in a Transforming Circumpolar World." In Canada and the Changing Arctic: Sovereignty, Security, and Stewardship, edited by R. Griffiths, R. Huebert, and P.W. Lackenbauer, 13-68. Waterloo: Wilfrid Laurier University Press.

Jennes, D. 1959. The People of the Twilight. Chicago: The University of Chicago Press.

Kafarowski, J. 2004. "Gender, Culture, and Contaminants in the North." Signs (34)3: 494-499.

Kalinovich, I., Rutter, A., Poland, J.S., Cairns, G., and R.K. Rowe. 2008.

"Remediation of PCB Contaminated Soils in the Canadian Arctic: Excavation and Surface PRB Technology." Science of the Total Environment 407: 53-66.

Kloppenburg, J. 1991. "No Hunting! Biodiversity, Indigeneous

Rights, and Scientific Poaching." Cultural Survival Quarterly

15(3). Accessed 6 August 2014. https://www.culturalsurvival.

org/publications/cultural-survival-quarterly/panama/

no-hunting-biodiversity-indigenous-rights-and-scient.

Krupar, S.H. 2013. Hot Spotter's Report: Military Fables of Toxic Waste. Minneapolis: University of Minnesota Press.

Lackenbauer, P.W. 2011. "From Polar Race to Polar Saga: An Integrated Strategy for Canada and the Circumpolar World." In Canada and the Changing Arctic: Sovereignty, Security, and Stewardship edited by F. Griffiths, R. Huebert, and P.W. Lackenbauer, 218-243.Waterloo: Wilfrid Laurier University Press.

Lackenbauer, P.W. 2011. "Sovereignty, Security, and Stewardship: An Update." In Canada and the Changing Arctic: Sovereignty, Security, and Stewardship edited by F. Griffiths, R. Huebert and P.W. Lackenbauer, 227-229. Waterloo: Wilfrid Laurier University Press.

Lackenbauer, P.W., and M. Farish. 2007. "The Cold War on Canadian Soil: Militarizing a Northern Environment." Environmental History 12: 920-950.

Lajeunesse, A. 2008. "The Distant Early Warning Line and the Canadian Battle for Public Perspective." National Defence and Canadian Armed Forces. Forces 8(2). http://www.journal.forces.gc.ca/vo8/no2/lajeunes-eng.asp

Locke, J. 1869/2011. Second Treatise of Government. New York: CreateSpace Independent Publishing Platform. 
Loock, D. 2014. "Distant Early Warning (DEW) Line." In Antartica and the Arctic Circle: A Geographic Encyclopedia of the Earth's Polar Regions, Vol. 1 edited by A.J. Hund, 229-231. Santa Barbara, CA: ABC-CLIO Greenwood.

Marcus, A. 1992. Out in the Cold: The Legacy of Canada's Inuit Relocation Experiment in the High Arctic. The International Working Group for Indigenous Affairs (IWGIA) Document 71.

Masco, J. 2006. The Nuclear Borderlands: The Manhattan Project in Post-Cold War New Mexico. Princeton: Princeton University Press.

McMahon, K. 1988. Arctic Twilight: Reflections on the Future of Canada's Northern Land and People. Toronto: James Lorimer and Company.

Myers, H. 2001. "Changing Environment, Changing Times: Environmental Issues and Political Action in the Canadian North." Environment: Science and Policy for Sustainable Development 43(6): 32-44.

Myers, H. and Munton, D. 2000. "Cold War, Frozen Wastes: Cleaning Up the DEW Line. " Environment and Sécurité 4: 119-138.

Paine, R., ed. 1977. The White Arctic: Anthropological Essays on Tutelage and Ethnicity. St. John's: Memorial University of Newfoundland.

Paudyn, K., Rutter, A., Rowe, R.K., Poland, J. 2008. "Remediation of Hydrocarbon Contaminated Soils in the Canadian Arctic by Landfarming." Cold Regions Science and Technology 53: 1-2-114.

Pigott, P. 2011. From Far and Wide: A Complete History of Canada's Arctic Sovereignty. Toronto: Dundurn.

Poland, J., Mitchell, S., and A. Rutter. 2001. "Remediation of Former Military Bases in the Canadian Arctic." Cold Regions Science and Technology 32: 93-105.

Qikiqtani Inuit Association. 2010. QTC Final Report: Achieving Saimaqatigiingniq. Accessed 16 July 2014. http://www.qtcommission.com/actions/GetPage. php?pageId=63.

Qikiqtani Truth Commission. 2013. Thematic Reports and Special Studies, 1950 1975. Iqaluit: Inhabit Media.

Reimer KJ., D.A. Bright, M. Dodd, W.T. Dushenko and K. Johnston, 1993. Environmental Study of Abandoned DEW Line Sites. I. Five Intermediate Sites from the Western and Central Arctic. VII-2

Rowe, R.K. 2012. "Third Indian Geotechnical Society Ferroco Terzaghi Oration: Design and Construction of Barrier Systems to Minimize Environmental Impacts Due to Municipal Solid Waste Leachate and Gas." Indian Geotechnical Journal 42(4): 223-256.

Sandlos, J. and A. Keeling. 2012. "Claiming the New North: Development and Colonialism at the Pine Point Mine, Northwest Territories, Canada." Environment and History 18: 5-34.

Saul, J.R. 2008. A Fair Country: Telling Truths About Canada. Toronto: Penguin Canada. 
Scanlan, J. 2005. On Garbage. London: Reaktion Books.

Shackleton, R. 2012. "Not Just Givers of Welfare: The Changing Role of the RCMP in the Baffin Region 1920-1970." Northern Review 36: 5-26.

Shadian, J. 2006. "Remaking Arctic Governance: The Construction of an Arctic Inuit Policy." Polar Record 42 (222): 249-259.

Southcott, C. 2012. "Can Resource Development Make Arctic Communities Sustainable?' Northern Public Affairs Spring: 48-49.

Tester, F.J. and P. Kulchyski. 1994. Tammarniit (Mistakes): Inuit Relocation in the Eastern Arctic 1939-63. Vancouver: UBC Press.

Thomassin-Lacroix, E. 2015. "Site Remediation of the Former DEW Line Site at FOX-3 Dewar Lakes, Nunavut." 2015 RPIC Federal Contaminated Sites Regional Workshop, Edmonton, Alberta.

Zahara, A. and M.J. Hird. 2015. "Raven, Dog, Human: Inhuman Colonialism and Unsettling Cosmologies." Environmental Humanities 7: 169-190. 